\title{
MOLECULAR DOCKING STUDIES ON SOME BENZAMIDE DERIVATIVES AS TOPOISOMERASE INHIBITORS
}

\author{
TOPOIZOMERAZ INHHIBITÖRLERI OLARAK BAZI BENZAMID TÜREVLERI \\ ÜZERINDE MOLEKÜLER DOKING ÇALIŞMALARI
}

\author{
Serap YILMAZ ${ }^{1, *}$, Sanaz ATAEI' ${ }^{2}$ ilkay YILDIZ ${ }^{2}$ \\ ${ }^{1}$ Trakya University, Faculty of Pharmacy, Department of Pharmaceutical Chemistry, 22030, \\ Edirne, Turkey \\ ${ }^{2}$ Ankara University, Faculty of Pharmacy, Department of Pharmaceutical Chemistry, 06100, \\ Ankara, Turkey
}

\begin{abstract}
Objective: In order to examine the interactions of some benzamide derivatives, which are thought to exhibit anti-cancer activity, with human Topo I and II enzymes at the molecular level, docking studies were carried out on these enzymes.

Material and Method: In conducting the docking studies, the protein was selected from the protein data bank for Topo I (1K4T) and for Topo II (5GWK). Doking was performed with the CDocker method using the Discovery studio 3.5 program, and the binding energies of benzamide derivatives to enzymes were calculated and their molecular interactions were revealed.

Result and Discussion: As a result of the docking process on Topo I and II , it was found that benzamide derivative compounds have higher affinity for Topo II enzyme. For Topo I compounds 4N6, 5N5; for Topo IIa compounds 5N3, 5N7 have been identified as promising compounds in terms of anticancer activity.

Keywords: Anticancer, Benzamide, Docking, Topoisomerase I, Topoisomerase II

\section{ÖZ}

Amaç: Antikanser aktivite göstereceği düşünülen Bazı benzamid türevlerinin insan Topo I ve II $\alpha$ enzimleri ile moleküler düzeydeki etkileşimlerinin incelenmesi amacılla bu enzimler üzerinden doking çalışmaları gerçekleştirilmiştir.
\end{abstract}

\footnotetext{
* Corresponding Author/Sorumlu Yazar: Serap Y1lmaz

e- mail/e-posta: serapyilmaz@ trakya.edu.tr
} 
Gereç ve Yöntem: Doking çalışmalarının gerçekleştirilmesinde protein veri bankasından Topo I için (1K4T) ve Topo II için (5GWK) seçilmiştir, Discovery studio 3.5 programı kullanılarak CDocker yöntemiyle doking işlemi yapılmış ve benzamid türevlerinin enzimlere bağlanma enerjileri hesaplanmış ve moleküler etkileşimleri ortaya çıkartılmıştır.

Sonuç ve Tartışma: Topo I ve II $\alpha$ üzerinden yapılan docking işlemi sonucunda benzamid türevi bileşiklerin Topo II enzimine afinitesinin daha yüksek olduğu bulunmuştur. 4N6, 5N5 bileşikleri Topo I; 5N3, $5 N 7$ bileşikleri de Topo II inhbitörleri olarak antikanser aktivite göstermesi açısından umut verici bileşikler olarak belirlenmiştir.

Anahtar Kelimeler: Antikanser, Benzamid, Doking, Topoizomeraz I, Topoizomeraz II

\section{INTRODUCTION}

DNA topoisomerases are the enzymes which play key roles on cellular processes such as replication, transcription, recombination and repair, and chromatin assembly by solving these topological problems of genomic DNA[1-7]. Because of their essential functions in cell cycle, they are significant targets for killing cancer cells or pathogenic bacteria. DNA topoisomerases are classified into two classes as Topo I and Topo II, depending on the number of broken strands of DNA by the enzymes in one reaction cycle. All type of topoisomerases indicates their biochemical functions by catalyzing DNA cleavage and relegation [8].

Topo I functions by generating transient single-stranded cuts in DNA supercoils relaxing torsional strain that has accumulated during DNA replication and transcription $[9,10]$. Intracellular levels of Topo I are upraised in some human solid tumors, relative to the corresponding normal tissues, suggesting that variations in Topo I levels are specific to the type of tumor [11-13]. DNA Topo I inhibitors, have recently emerged as a prominent class of anticancer agents with a novel mechanism of action, potent antiproliferative activity on a widespectrum of tumor cells including multidrug-resistant lines, and fascinating activity in xenograft models [14]. At first, camptothecin was discovered as a Topo I inhibitor in 1966, but could not be used in the clinic due to unpredictable and severe myelo suppression, gastrointestinal toxicity, and hemorrhagiccystitis [15]. Afterwards, it was found that the FDA approved anticancer agents topotecan and irinotecan, which are the analogue of camptothecin, inhibited the Topo I activity by intercalating into the cleavage complex and preventing the religation step of the catalytic cycle $[16,17]$.

Topo II cuts both strands of DNA by the enzymes in one reaction circle. Human Topo II have two available isoforms as $\alpha$ and $\beta$. Both of them sharing a similar tertiary structure and primary sequence, and perform similar functions but their levels differ depending on the replicative activity and type of tissue [18-20]. They also show various cellular functions, Topo II $\alpha$ overexpressed in proliferating cells and generally located in the nuclearplasma. Topo II $\beta$ plays apparent roles in transcriptional regulation, cell development, and differentiation, but not essential for cell 
proliferation and survival. Although human Topo II $\alpha$ relaxes negatively supercoiled plasmid slower than positively supercoiled plasmids, but Topo II $\beta$ is not. Thus selective Topo II $\alpha$ inhibitors have been of particular interest in cancer therapy, as they may represent a more targeted approach to highly proliferative cells [21-24]. Doxorubicin and Etoposide, classified as DNA Topo II inhibitors, have recently emerged as a prominent class of anticancer agents. Topo II inhibitors prevents re-ligation of the DNA strands, and breaks the DNA strands. Cancer cells depend on this enzyme more than healthy cells, for that they divide more rapidly. Therefore, this generates errors in DNA synthesis and promotes apoptosis of the cancer cell [10,25].

Recently, amide derivatives received significant attention for their antitumor properties, especially the compounds which containing benzamide pharmacophore. The benzamide derivatives have been reported for their wide range of pharmacological activities including antitumor [26], histone deacetylase inhibition [27] and CYP24A1 inhibitory activity [28]. In addition to these activities some benzamide derivatives were used as HDAC inhibitors [29], glucokinase activators [30], antiprion agents [31] and topoisomerase inhibitors [32, 33] etc.

Recent developments in the field of cell biology want to introduce selective anticancer agents with low side effects to the pharmaceutical market, and the promising bioactive diversity of benzamide derivatives made us think that these derivatives will act as topoisomerase inhibitors, and in this study, the docking studies were performed to elucidate the interactions between various previously synthesized benzamide derivatives [34] and human Topo I and II $\alpha$ enzymes and were aimed to identify a new type of anticancer drug candidates which have suitable properties to be promising oral human Topo I and II $\alpha$ inhibitors.

\section{MATERIAL AND METHOD}

\section{Preparation of the enzyme}

Human Topo I has monomer structure and composed of 765 amino acids and human Topo II $\alpha$ has a homo dimer structure and its monomer is composed of 1531 amino acids including four sections DNA-gate, Ngate, C-gate, and CTD [35]. The X-ray crystallographic structure of Topo I (PDB: 1K4T) and Topo II $\alpha$ (PDB: 5GWK) are available in Protein Data Bank and further modified for docking calculations [36]. For preparation of protein Discovery Studio 3.5 software [37] was used. The target proteins were taken, hydrogens were added and their positions were optimized using the all atom CHARMm [38] force field and the Adopted Basis set Newton Raphson (ABNR) method [39] available in the D.S 3.5 protocol until the root mean square deviation (RMSD) gradient was $<0.05 \mathrm{kcal} / \mathrm{mol} \AA 2$. The minimized protein was defined as the receptor using the binding site module. 
The binding site was defined from current selection around the ligand inside. The binding sphere were selected for 1K4T 6.12, 47.51, 26.54, 14.67 (Figure 1A) and for 5GWK 31.34, -23.16, -57.75, 10.32 (Figure 1B) from the active site using the binding site tools.
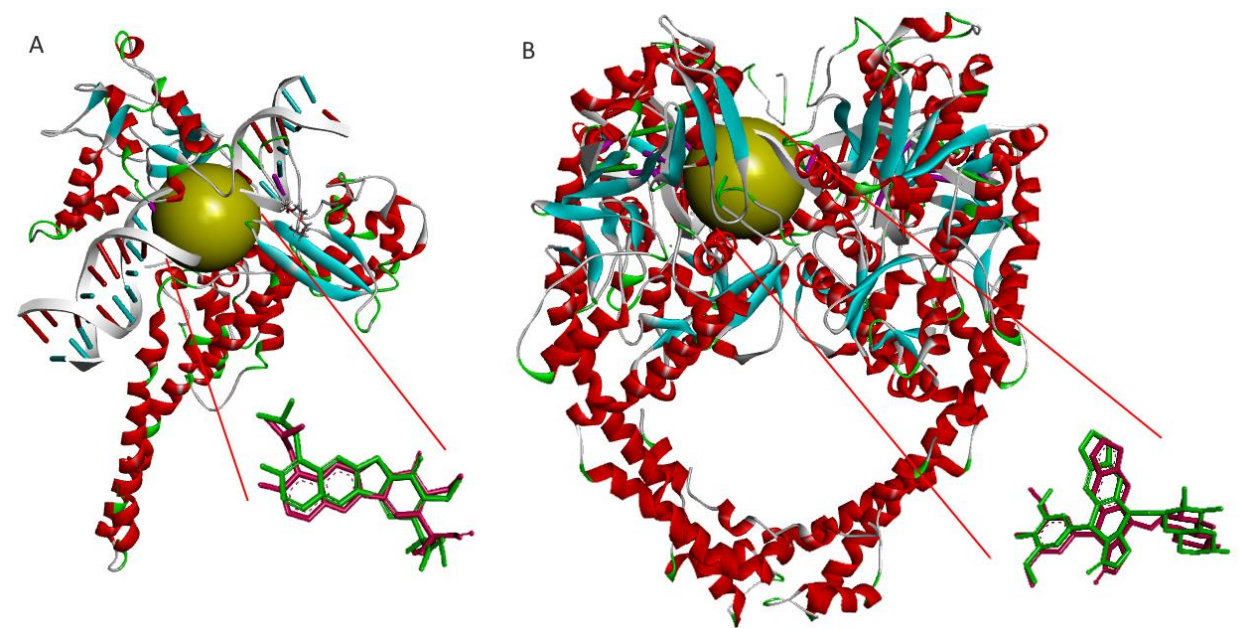

Figure 1. A. Topo I (pdb:1K4T) enzyme, the active site is located inside the sphere marked in yellow, superimpose position of Camptothecin with RMSD:1.2424. B. Topo II $\alpha$ (pdb:5GWK) enzyme, the active site is located inside the sphere marked in yellow, superimpose position of Etoposide with RMSD:1.7219.

\section{Preparation of ligands}

Benzamide derivatives [34] given in Table 1, selected inhibitors Camptothecin and Etoposide were sketched with ChemDraw Professional; all-atom CHARMm force field parameterization was assigned and then minimized using the ABNR method as described above.

Table 1. Benzamide derivatives tested in molecular docking process

\begin{tabular}{|c|l|l|l|l|l|l|}
\hline \multicolumn{7}{|c|}{} \\
\hline \multicolumn{7}{|c|}{} \\
\hline COMPOUND & $\mathbf{R}$ & $\mathbf{R}^{\prime}$ & $\mathbf{R}_{1}$ & $\mathbf{R}_{2}$ & $\mathbf{R}_{3}$ & $\mathbf{R}_{4}$ \\
\hline $\mathbf{4 N 1}$ & $\mathrm{NO}_{2}$ & $\mathrm{H}$ & $\mathrm{H}$ & $\mathrm{H}$ & $\mathrm{C}_{4} \mathrm{H}_{9}$ & $\mathrm{H}$ \\
\hline $\mathbf{4 N 2}$ & $\mathrm{NO}_{2}$ & $\mathrm{H}$ & $\mathrm{H}$ & $\mathrm{H}$ & $\left.\mathrm{C}_{(} \mathrm{CH}_{3}\right)_{3}$ & $\mathrm{H}$ \\
\hline $\mathbf{4 N 3}$ & $\mathrm{NO}_{2}$ & $\mathrm{H}$ & $\mathrm{H}$ & $\mathrm{H}$ & $\mathrm{OC}_{2} \mathrm{H}_{5}$ & $\mathrm{H}$ \\
\hline $\mathbf{4 N 4}$ & $\mathrm{NO}_{2}$ & $\mathrm{H}$ & $\mathrm{H}$ & $\mathrm{H}$ & $\mathrm{OC}_{4} \mathrm{H}_{9}$ & $\mathrm{H}$ \\
\hline $\mathbf{4 N 5}$ & $\mathrm{NO}_{2}$ & $\mathrm{H}$ & $\mathrm{H}$ & $\mathrm{CH}_{3}$ & $\mathrm{H}$ & $\mathrm{CH}_{3}$ \\
\hline $\mathbf{4 N 6}$ & $\mathrm{NO}_{2}$ & $\mathrm{H}$ & $\mathrm{H}$ & $\mathrm{OCH}_{3}$ & $\mathrm{H}$ & $\mathrm{HCH}_{3}$ \\
\hline $\mathbf{5 N 1}$ & $\mathrm{H}$ & $\mathrm{NO}_{2}$ & $\mathrm{H}$ & $\mathrm{H}$ & $\mathrm{C}_{2} \mathrm{H}_{5}$ & $\mathrm{H}$ \\
\hline $\mathbf{5 N 2}$ & $\mathrm{H}$ & $\mathrm{NO}_{2}$ & $\mathrm{H}$ & $\mathrm{H}$ & $\left.\mathrm{C}_{(} \mathrm{CH}_{3}\right)_{3}$ & $\mathrm{H}$ \\
\hline $\mathbf{5 N 3}$ & $\mathrm{H}$ & $\mathrm{NO}_{2}$ & $\mathrm{H}$ & $\mathrm{H}$ & $\mathrm{OC}_{2} \mathrm{H}_{5}$ & $\mathrm{H}$ \\
\hline $\mathbf{5 N 4}$ & $\mathrm{H}$ & $\mathrm{NO}_{2}$ & $\mathrm{H}$ & $\mathrm{H}$ & $\mathrm{OC}_{4} \mathrm{H}_{9}$ & $\mathrm{H}$ \\
\hline $\mathbf{5 N 5}$ & $\mathrm{H}$ & $\mathrm{NO}_{2}$ & $\mathrm{CH}$ & $\mathrm{H}$ & $\mathrm{CH}_{3}$ & $\mathrm{H}$ \\
\hline $\mathbf{5 N 6}$ & $\mathrm{H}$ & $\mathrm{NO}_{2}$ & $\mathrm{H}$ & $\mathrm{CH}$ & $\mathrm{H}$ & $\mathrm{CH}$ \\
\hline $\mathbf{5 N 7}$ & $\mathrm{H}$ & $\mathrm{NO}_{2}$ & $\mathrm{H}$ & $\mathrm{OCH}_{3}$ & $\mathrm{H}$ & $\mathrm{OCH}_{3}$ \\
\hline & & & & & \\
\hline
\end{tabular}




\section{Validation of Docking Process}

In order to validate the accuracy of the process, docking studies were performed using the CDOCKER method [40] to the region determined on the proteins of the ligands carried by the enzymes. RMSD values were calculated by overlapping the obtained poses with the ligand found in the X-ray crystallography of the protein. The RMSD values expressing the difference between the optimal conformation of the ligand and X-ray crystallography were found to be 1.2424 (Figure 1A) and 1.7219 (Figure 1B) for 1K4T and 5GWK, respectively.

\section{Molecular Docking}

Docking process was performed using the CDOCKER method in which the ligand moves flexibly while keeping the receptor stable. Ligands were interacted in 3000 different conformations in the active site of the enzyme. After the validation step, docking processes of benzamide derivatives and selected inhibitors were performed. Among the poses obtained as a result of these processes, the most suitable ones were determined, and their binding energies were calculated.

\section{RESULT AND DISCUSSION}

The interactions of benzamide derivatives with Topo I and II $\alpha$ enzymes have been elucidated by applying molecular docking processes, and it has been found that the compounds generally show a better interaction with the Topo II $\alpha$ enzyme. When benzamide derivatives and Camptothecin were docked in the active site of the $1 \mathrm{~K} 4 \mathrm{~T}$ enzyme selected from pdb as the Topo I enzyme, they show various interactions with residues DT10, DG12, DA113, DC112 and TGP11 of DNA and amino acids ASN352, GLU356, ARG364, TRP416, LYS425 and THR718 of enzyme as given in Table 2 and the binding energies of these compounds also range between $-57,7457$ and $97.388 \mathrm{kcal} / \mathrm{mol}$. The interactions of Camptothecin, Topo I enzyme inhibitor, were examined, it was observed that it binds to the enzyme with $-16,5852 \mathrm{kcal} / \mathrm{mol}$ binding energy and interacted with LYS425 amino acid and DT10, DA113, DC112, TGP11 residues, as given Figure 2A. Compounds 4N6, 5N5, 4N2, 5N4, 4N4, 4N3 and 5N3 were interacted with lower binding energies than Camptothecin to the enzyme respectively, while other compounds exhibited positive binding energies. The compound 4N6 gave the best binding energy $(-57,7457 \mathrm{kcal} / \mathrm{mol})$ with Topo I enzyme and interacted with GLU356, TGP11, DC112, DA113 residues through phenyl and hydroxyl groups in the molecule, as given Figure 2B. The compound 5N5 showed a good interaction with Topo I enzyme with its binding energy of $-50,3612 \mathrm{kcal} / \mathrm{mol}$ and made $\mathrm{H}$ bond to DA113 residue with its hydroxyl group and showed 
pi interactions between phenyl rings and DT10, TGP11, DC112, DA113 residues, as given Figure 2C.

Table 2. Interaction properties of benzamide derivatives with Topo I

\begin{tabular}{|l|l|l|l|l|}
\hline Compound & $\begin{array}{l}\text { binding } \\
\text { energy } \\
\text { (kcal/mol) }\end{array}$ & $\begin{array}{l}\text { conventional } \\
\text { Hydrogen Bond }\end{array}$ & $\begin{array}{l}\text { carbon } \\
\text { Hydrogen bond }\end{array}$ & Pi Interactions \\
\hline 4N1 & 97.388 & THR718, TGP11 & DG12 & DC112, DA113 \\
\hline 4N2 & $-37,6963$ & - & DA113 & TGP11, DA113, LYS425 \\
\hline 4N3 & $-23,5498$ & ASN352 & DT10 & DA113, TGP11, \\
\hline 4N4 & $-32,0942$ & ASN352 & DT10 & DA113 \\
\hline 4N5 & 30,0267 & DC112, DA113, ARG364 & TGP11 & DT10 \\
\hline 4N6 & $-57,7457$ & - & GLU356, DC112, DA113 & TGP11 \\
\hline $\mathbf{5 N 1}$ & $-19,2227$ & TGP11 & - & TRP416, LYS425 \\
\hline $\mathbf{5 N 2}$ & 0,04961 & TGP11 & - & DA113, TRP416, LYS425 \\
\hline $\mathbf{5 N 3}$ & $-22,824$ & DT10 & - & DC112, DA113 \\
\hline & $-35,4994$ & ASN352 & DT10 & GLU356, TGP11, DC112, \\
\hline $\mathbf{5 N 4}$ & $-50,3612$ & DA113 & - & DA113 \\
\hline $\mathbf{5 N 5}$ & 15,7991 & - & TGP11 & DT10, TGP11, DC112 \\
\hline $\mathbf{5 N 6}$ & 2,02614 & ASN352 & DT10, DA113, TGP11 & - \\
\hline 5N7 & $-16,5852$ & - & LYS425 & DT10, TGP11, DC112, DA113 \\
\hline Camptothecine & &
\end{tabular}

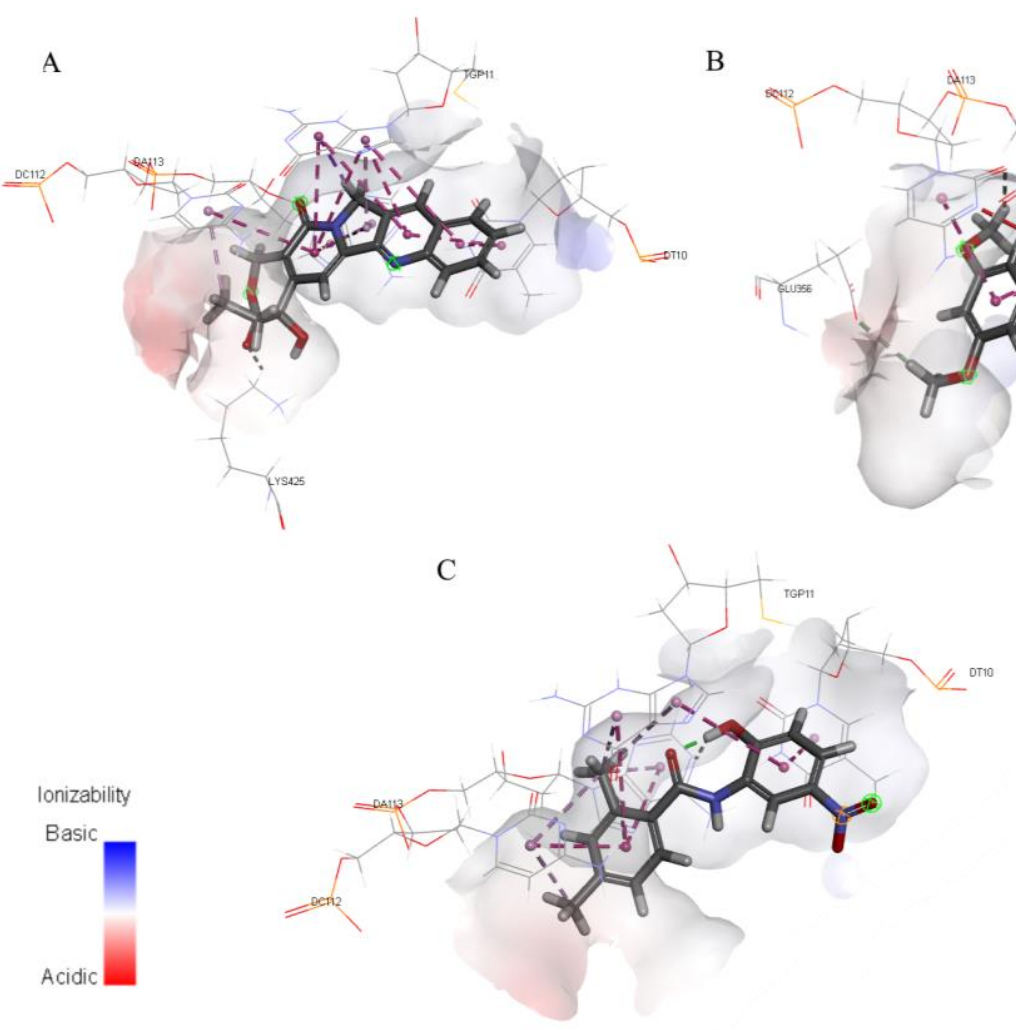

Figure 2. Molecular interactions of the Topo I enzyme A. Docked pose of Camptothecine, B. Docked pose of compound 4N6, C. Docked pose of compound 5N5. 
When benzamide derivatives and Etoposide were docked in the active site of the 5GWK enzyme selected from pdb as the Topo II $\alpha$ enzyme, they show various interactions with residues DC8, DT9, DG10, DC11, DA12, DG13 and DC14 of DNA and amino acids GLY462, ARG487, GLY760, MET762 and TYR805 of enzyme as given in Table 3 and the binding energies of these compounds also range between $-114,71$ and $-60,1444 \mathrm{kcal} / \mathrm{mol}$. The interactions of Etoposide, Topo II $\alpha$ enzyme inhibitor, were examined, it was observed that it binds to the enzyme with $-114,71$ $\mathrm{kcal} / \mathrm{mol}$ binding energy and made $\mathrm{H}$ bond to DG13 residue with its hydroxyl group. It also interacted with LYS440, ARG487 amino acids and DT9, DA12, DG13, ARG487 residues, as given Figure 3A. The binding energies of benzamide derivatives were higher than etoposide, but it was observed that all molecules interacted with the enzyme with low binding energies. Compounds 5N3 and 5N7 indicated good interactions with the Topo II $\alpha$ enzyme with binding energies of -94,3762 and $92,0598 \mathrm{kcal} / \mathrm{mol}$, respectively. The compound $5 \mathrm{~N} 3$ made $\mathrm{H}$ bond to DG13 residue with its nitrogen atom in amide group and also interacted with ARG487, DC8, DT9 residues, as given Figure 3B. The compound 5N7 made $\mathrm{H}$ bond to ARG487 with its methoxy group and showed pi interactions with DC8, DT9, DA12, DG13 residues, as given Figure 3C.

Table 3. Interaction properties of benzamide derivatives with Topo II $\alpha$

\begin{tabular}{|l|l|l|l|l|}
\hline Compound & $\begin{array}{l}\text { binding energy } \\
\text { (kcal/mol) }\end{array}$ & $\begin{array}{l}\text { conventional } \\
\text { Hydrogen Bond }\end{array}$ & $\begin{array}{l}\text { carbon } \\
\text { Hydrogen bond }\end{array}$ & Pi Interactions \\
\hline 4N1 & $-74,4069$ & DT9, ARG487 & DG13 & DC8, DA12 \\
\hline 4N2 & $-74,456$ & TYR805 & GLY462 & ARG487, DG13 \\
\hline 4N3 & $-65,2691$ & DT9 & DG13 & ARG487, MET762, DG8, DG13 \\
\hline 4N4 & $-88,0887$ & DT9 & DG13 & DC8, DA12 \\
\hline 4N5 & $-62,9599$ & DG13 & GLY760 & DA12 \\
\hline 4N6 & $-65,1616$ & DT9 & DG13 & DC8, DA12 \\
\hline $\mathbf{5 N 1}$ & $-75,7866$ & DT9, ARG487 & & MET762, DC8, DT9, DG13 \\
\hline $\mathbf{5 N 2}$ & $-61,5032$ & & & DC8, DT9 \\
\hline $\mathbf{5 N 3}$ & $-94,3762$ & DG13 & ARG487 & DC8, DT9 \\
\hline $\mathbf{5 N 4}$ & $-90,2323$ & DT9, DC14 & & DC8, DT9, ARG487 \\
\hline $\mathbf{5 N 5}$ & $-60,1444$ & DG13 & GLY760 & ARG487, DC8, DT9 \\
\hline $\mathbf{5 N 6}$ & $-87,8215$ & DG13 & & DC8, DT9 \\
\hline $\mathbf{5 N 7}$ & $-92,0598$ & ARG487 & & DC8, DT9, DA12, DG13 \\
\hline & & DG13 & AG10, DC11, DA12, LYS440, & DT9, DA12, DG13, ARG487 \\
\hline
\end{tabular}


A

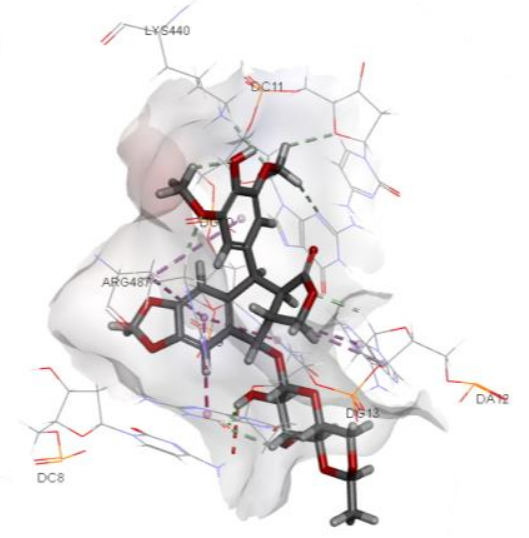

B

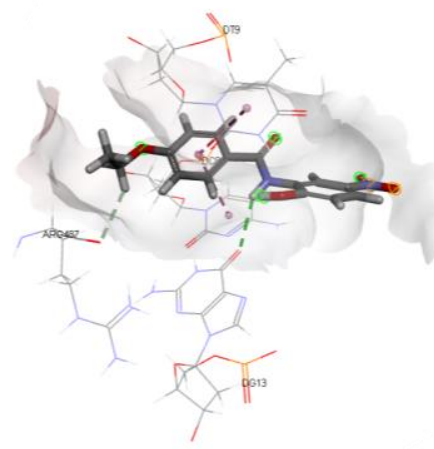

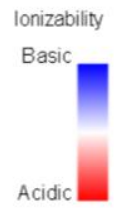

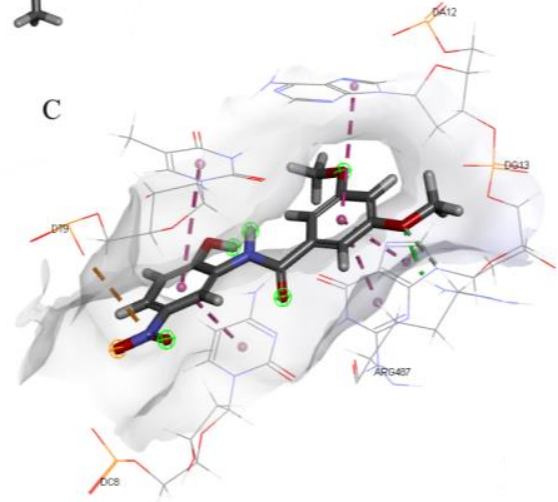

Figure 3. Molecular interactions of the Topo II $\alpha$ enzyme A. Docked pose of Etoposide, B. Docked pose of compound 5N3, C. Docked pose of compound 5N7.

As a result of the docking studies on Topo I and II $\alpha$ enzymes of benzamide derivatives, which are thought to have anticancer activity as topoisomerase inhibitors, it has been shown that the compounds have higher affinity for the Topo II $\alpha$ enzyme, but have a lower effect than the reference compound. However, most of the compounds docked on Topo I enzyme were performed better results than the reference molecule. The performed docking studies should be supported by experimental results, but its clear that the accompanying results represent that compounds are promising inhibitors for Topo I and II $\alpha$ enzymes.

\section{REFERENCES}

1. Holden, J.A. (2001). DNA Topoisomerases as anticancer drug targets from the laboratory to the clinic. Current Medicinal Chemistry-Anti-Cancer Agents. 1(1), 1-25.

2. Topcu, Z. (2001). DNA topoisomerases as targets for anticancer drugs. Journal of clinical pharmacy and therapeutics. 26(6), 405-416. 
3. Wang, J.C. (1996). DNA topoisomerases. Annual review of biochemistry. 65(1), 635-692.

4. Berger, J.M. (1998). Structure of DNA topoisomerases. Biochimica et Biophysica Acta (BBA)-Gene Structure and Expression. 1400 (1-3), 3-18.

5. Kaufmann, S.H. (1998). Cell death induced by topoisomerase-targeted drugs: more questions than answers. Biochimica et Biophysica Acta (BBA)-Gene Structure and Expression. 1400 (1-3), 195-211.

6. Pommier, Y. (1998). Diversity of DNA topoisomerases I and inhibitors. Biochimie. 80(3), 255-270.

7. Redinbo, M.R., Stewart, L., Kuhn, P., Champoux, J.J., Hol, W.G. (1998). Crystal structures of human topoisomerase I in covalent and noncovalent complexes with DNA. Science. 279 (5356), 1504-1513.

8. $\quad$ Cowell, I.G., Sondka, Z., Smith, K., Lee, K.C., Manville, C.M., Sidorczuk-Lesthuruge, M. , Rance, H.A., Padget, K., Jackson, G.H., Adachi, N. (2012). Model for MLL translocations in therapy-related leukemia involving topoisomerase II $\beta$-mediated DNA strand breaks and gene proximity. Proceedings of the National Academy of Sciences. 109(23), 8989-8994.

9. Wang, J.C.. (2002). Cellular roles of DNA topoisomerases: a molecular perspective. Nature reviews Molecular cell biology. 3(6), 430-440.

10. Pommier, Y., Leo, E., Zhang, H., Marchand, C. (2010). DNA topoisomerases and their poisoning by anticancer and antibacterial drugs. Chemistry \& biology. 17(5), 421-433.

11. Giovanella, B.C., Stehlin, J.S., Wall, M.E., Wani, M.C., Nicholas, A.W., Liu, L.F., Silber, R., Potmesil, M. (1989). DNA topoisomerase I--targeted chemotherapy of human colon cancer in xenografts. Science. 246(4933),1046-1048.

12. Husain, I., Mohler, J.L., Seigler, H.F., Besterman, J.M. (1994). Elevation of topoisomerase I messenger RNA, protein, and catalytic activity in human tumors: demonstration of tumortype specificity and implications for cancer chemotherapy. Cancer research. 54(2), 539-546.

13. Lima, C.D., Wang, J.C., Mondragón, A. (1994). Three-dimensional structure of the 67K Nterminal fragment of E. coli DNA topoisomerase I. Nature. 367(6459), 138-146.

14. Garcia-Carbonero, R., Supko, J.G. (2002). Current perspectives on the clinical experience, pharmacology, and continued development of the camptothecins. Clinical Cancer Research. $8(3), 641-661$.

15. Wall, M.E., Wani, M.C., Cook, C., Palmer, K.H., McPhail, A.A., Sim, G. (1966). Plant antitumor agents. I. The isolation and structure of camptothecin, a novel alkaloidal leukemia and tumor inhibitor from camptotheca acuminata1, 2. Journal of the American Chemical Society. 88(16), 3888-3890.

16. Thomas, C.J., Rahier, N.J., Hecht, S.M. (2004). Camptothecin: current perspectives. Bioorganic \& medicinal chemistry. 12(7), 1585-1604. 
17. Teicher, B.A. (2008). Next generation topoisomerase I inhibitors: Rationale and biomarker strategies. Biochemical pharmacology. 75(6), 1262-1271.

18. Nitiss, J.L. (2009). DNA topoisomerase II and its growing repertoire of biological functions. Nature Reviews Cancer. 9(5), 327-337.

19. Pogorelcnik, B., Perdih, A., Solmajer, T. (2013). Recent advances in the development of catalytic inhibitors of human DNA topoisomerase II $\alpha$ as novel anticancer agents. Current medicinal chemistry. 20, 694-709.

20. Schmidt, B.H., Osheroff, N., Berger, J.M. (2012). Structure of a topoisomerase II-DNAnucleotide complex reveals a new control mechanism for ATPase activity. Nature structural \& molecular biology. 19, 1147.

21. Larsen, A.K., Escargueil, A.E., Skladanowski, A. (2003). Catalytic topoisomerase II inhibitors in cancer therapy. Pharmacology \& therapeutics. 99, 167-181.

22. Farr, C.J., Antoniou-Kourounioti, M., Mimmack, M.L., Volkov, A., Porter, A.C. (2014). The $\alpha$ isoform of topoisomerase II is required for hypercompaction of mitotic chromosomes in human cells. Nucleic acids research. 42, 4414-4426.

23. Arcy, D. N., Gabrielli, B. (2017). Topoisomerase II inhibitors and poisons, and the influence of cell cycle checkpoints. Current Medicinal Chemistry. 24, 1504-1519.

24. McClendon, A.K., Rodriguez, A.C., Osheroff, N. (2005). Human topoisomerase II $\alpha$ rapidly relaxes positively supercoiled DNA implications for enzyme action ahead of replication forks. Journal of Biological Chemistry. 280, 39337-39345.

25. Hande, K. (1998). Etoposide: four decades of development of a topoisomerase II inhibitor. European journal of cancer. 34, 1514-1521.

26. Zhang, J., Yang, P.L., Gray, N.S. (2009). Targeting cancer with small molecule kinase inhibitors. Nature Reviews Cancer. 9, 28-39.

27. Lu, A., Luo, H., Shi, M., Wu, G., Yuan, Y., Liu, J., Tang, F. (2011). Design, synthesis and docking studies on benzamide derivatives as histone deacetylase inhibitors. Bioorganic \& medicinal chemistry letters. 21, 4924-4927.

28. Aboraia, A.S., Yee, S.W., Gomaa, M.S., Shah, N., Robotham, A.C., Makowski, B., Prosser, D., Brancale, A., Jones, G., Simons, C. (2010). Synthesis and CYP24A1 inhibitory activity of N-(2-(1H-imidazol-1-yl)-2-phenylethyl) arylamides. Bioorganic \& medicinal chemistry. $18,4939-4946$.

29. Li, Y., Zhou, Y., Qian, P., Wang, Y., Jiang, F., Yao, Z., Hu, W., Zhao, Y., Li, S. (2013). Design, synthesis and bioevalution of novel benzamides derivatives as HDAC inhibitors. Bioorganic \& medicinal chemistry letters. 23, 179-182.

30. Mao, W., Ning, M., Liu, Z., Zhu, Q., Leng, Y., Zhang, A. (2012). Design, synthesis, and pharmacological evaluation of benzamide derivatives as glucokinase activators. Bioorganic \& medicinal chemistry. 20, 2982-2991. 
31. Fiorino, F., Eiden, M., Giese, A., Severino, B., Esposito, A., Groschup, M.H., Perissutti, E., Magli, E., Incisivo, G.M., Ciano, A. (2012). Synthesis of benzamide derivatives and their evaluation as antiprion agents. Bioorganic \& medicinal chemistry. 20, 5001-5011.

32. Kamal, A., Suresh, P., Ramaiah, M.J., Srinivasa Reddy, T., Kapavarapu, R.K., Rao, B.N., Imthiajali, S., Lakshminarayan Reddy, T., Pushpavalli, S.N.C.V.L., Shankaraiah, N., PalBhadra, M. (2013). 4 $\beta$-[4'-(1-(Aryl)ureido)benzamide] podophyllotoxins as DNA topoisomerase I and II $\alpha$ inhibitors and apoptosis inducing agents. Bioorganic \& Medicinal Chemistry. 21, 5198-5208.

33. Kamal, A., Suresh, P., Ramaiah, M.J., Mallareddy, A., Imthiajali, S., Pushpavalli, S.N.C.V.L., Lavanya, A., Pal-Bhadra, M. (2012). Synthesis and biological evaluation of $4 \beta-$

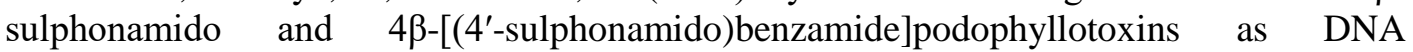
topoisomerase-II $\alpha$ and apoptosis inducing agents. Bioorganic \& Medicinal Chemistry. 20, 2054-2066.

34. Acar, C., Yalcin, G., Ertan-Bolelli, T., Onurdag, F.K., Okten, S., Sener, F., Yildiz, I. (2020). Synthesis and molecular docking studies of some novel antimicrobial benzamides. Bioorganic Chemistry. 94, 103368.

35. Wendorff, T.J., Schmidt, B.H., Heslop, P., Austin, C.A., Berger, J.M. (2012). The structure of DNA-bound human topoisomerase II alpha: conformational mechanisms for coordinating inter-subunit interactions with DNA cleavage. Journal of molecular biology. 424, 109-124.

36. Wang, Y.-R., Chen, S.-F., Wu, C.-C., Liao, Y.-W., Lin, T.-S., Liu, K.-T., Chen, Y.-S., Li, T.-K., Chien, T.-C., Chan, N.-L. (2017). Producing irreversible topoisomerase II-mediated DNA breaks by site-specific Pt (II)-methionine coordination chemistry. Nucleic acids research. 45, 10861-10871.

37. Accelrys, Discovery Studio 3.52012.

38. Momany, F.A., Rone, R. (1992). Validation of the general purpose QUANTA® 3.2/CHARMm® force field. Journal of Computational Chemistry. 13, 888-900.

39. Crisfield, M. (1979). A faster modified Newton-Raphson iteration. Computer Methods in Applied Mechanics and Engineering. 20, 267-278.

40. Wu, G., Robertson, D.H., Brooks III, C.L., Vieth, M. (2003). Detailed analysis of grid-based molecular docking: A case study of CDOCKER - A CHARMm-based MD docking algorithm. Journal of computational chemistry. 24, 1549-1562. 